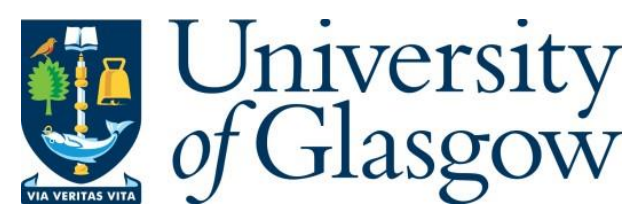

Alexander, P. (2019) Narratives of here and of elsewhere in Scottish-Jewish music: Meyer Fomin and Isaac Hirshow. Shofar, 37(3), pp. 19-58.

There may be differences between this version and the published version. You are advised to consult the publisher's version if you wish to cite from it.

http://eprints.gla.ac.uk/189247/

Deposited on: 1 July 2019

Enlighten - Research publications by members of the University of Glasgow http://eprints.gla.ac.uk 


\title{
Narratives of here and of elsewhere in Scottish Jewish Music: Meyer Fomin and Isaac
} Hirshow

Philip Alexander, University of Glasgow, Philip.Alexander@glasgow.ac.uk

\begin{abstract}
This article analyzes the role of music in the negotiation of Scottish-Jewish identity in early twentieth century Glasgow through the lives and work of Isaac Hirshow (1883-1956) and Meyer Fomin (1886-1960), cantors of Garnethill and South Portland Street synagogues respectively. Both men were born in Vitebsk province in Russia, both established their reputations in Warsaw, and both moved to Glasgow in the early 1920s, remaining there for the rest of their lives. An analysis of these men's parallel journeys suggests a fruitful dialogue between their own backgrounds and the varied identities of their Scottish congregations. Drawing on archive materials, newspaper reports and musical examples, I therefore explore the ways in which these cantors and their music were both metonymic of a real and known Eastern Europe for immigrant populations, but also metaphoric of an (often fondly) imagined Eastern Other to those for whom roots were often multiple. I then discuss in detail a number of musical texts created by the two men after their arrival in the UK: a series of commercial recordings made by Meyer Fomin in 1922, and a cantata written by Isaac Hirshow as part of his 1938 BMus degree. These texts capture a perspective that looks two ways at once- to the 'tradition' and history of Eastern Europe, and to the modernity of the West and the acculturation of an immigrant experience. The texts thus speak to a moment of transition, simultaneously framing and problematizing discourses of authenticity as expressed through material cultural production.
\end{abstract}

The 'right' tune grounds one in history (Jeffrey Summit, The Lord's Song)

\section{Introduction: Sound as Jewish History}

On January $24^{\text {th }} 1939$, a little over seven months before the onset of the Second World War, a broadcast performance was given by the Glasgow Jewish Institute Male Voice Choir. Transmitted on the BBC's Regional Service, the programme-according to the Radio Times_-included “arrangements of Modern Palestinian Folk Songs, ‘Creation's Hymn’ by 
Beethoven, and 'Zemer Le-Shabbos' by the choir's leader I. Balkan.” The concert took place at the South Portland Street Jewish Institute, a purpose-built structure next door to the Great Synagogue in Glasgow's Gorbals, an area on the south side of the city that at this time was home to approximately 10,000 Jews. Many had arrived with the large waves of East-West migration that took place between the early 1880s and the mid-1920s. They had come from the great European Jewish cities like Warsaw and Vilna, or from the small villages and market towns - the shtetls that had structured economic life in the Polish-Lithuanian commonwealth and the Pale of Settlement-as Scottish novelist Lewis Grassic Gibbon put it in 1934, "sun-warmed and ripened under alien suns."1

These Eastern European immigrants weren't the only Jews in Glasgow; they were just the newest ones. North from the Gorbals, across the river Clyde, the Glasgow Hebrew Congregation had been established in 1823. The next fifty years saw a number of small synagogues open around the center of the city, and in 1875 an imposing hilltop site was purchased on the corner of Garnet and Hill Streets, followed by the construction and consecration — in 1879—of an equally impressive synagogue building similar in detail to the 'Moorish' style of London's well-known New West End synagogue. ${ }^{2}$ Garnethill synagogue, unlike its Gorbals counterparts, still stands today-even as its congregant numbers are vastly reduced. These Garnethill Jews were by and large reasonably wealthy. Most lived in and around the city center. The majority were middle-class, cosmopolitan, and anglicized. By contrast, the post-1880s Gorbals immigrants were mostly poor, Yiddish-speaking Jews. They included those who were more orthodox in their observance, and also those more radical in their politics - though rarely in the same individual. Many simply passed through Glasgow on their way to America (others thought they had already arrived in America). Many, intending to pass through, ended up staying. And right up until the Second World War, links between Scotland and the 'old country' remained strong and sustained.

These different positions point to a complex of Scottish-Jewish identities, a spectrum that faced in several directions, living — as painter RB Kitaj proclaimed_- “in two or more societies at once”. ${ }^{3}$ We can see how these multiple narratives — of home, of exile, of social and religious identity—-find their musical parallels in the BBC broadcast described above. Modern Palestinian Folk Songs, pre-1948, point both to music's future role in the construction of early Israeli statehood ${ }^{4}$ and to the symbiotic relationship between the diaspora and the Holy Land—nationalist sentiment here finding cultural expression amongst golus 
[diaspora] Jews in Scotland. At the same time, the classical canon in the form of Beethoven marks an aural nod to Western high-art traditions, but more specifically Jewish claims to participation within them, whilst choirmaster Isidor Balkan's own para-liturgical composition Zemer Le-Shabbos makes a case for a rooted contemporary Jewish religious selfhood, as expressed through musical production. And with this musical multiplicity comes a similarly diffuse discourse of identity. Who were the male voice choir, with their soloists Balkan and Markson, singing as? Jews, Scots, Zionists...Glaswegians? Likewise we might question whether their inclusion as part of the BBC apparatus positions them within establishment multiculturalism, or as an exoticized Other. Cultural assertions like this concert made a case for specifically Jewish life and musical creativity, whilst simultaneously propping up a discourse of difference that would continue to problematize top-down ideologies of integration, indexing inherent ambiguities within immigrant Jewish identities and their transformation through assimilation.

This article examines some of these processes through the filter of two of the most important figures in Scottish Jewish liturgical music: Isaac Hirshow (1883-1956) and Meyer Fomin (1888-1960). These men are part of a larger group of synagogue cantors and musical community leaders who settled in Scotland throughout the early twentieth century, but they are among the very few who, once here, remained for the rest of their lives. ${ }^{5}$ Unlike a number of successful and highly-esteemed cantors who passed through Scotland—often staying for several years — on their way to posts in London, ${ }^{6}$ Isaac Hirshow and Meyer Fomin made Scotland their home and Glasgow their place of work for the majority of their careers. They are a part of Glasgow Jewish cultural memory. As the first step towards a more comprehensive history, what follows also touches upon their lives before immigrating to Scotland—offering important context through which to understand Hirshow and Fomin's mediating relationship between the Eastern European tradition that they represented and their adopted home.

Both men were born in Vitebsk province in Belarus, both worked and began families in preand interwar Warsaw, and both emigrated to Scotland in the early 1920s, leaving successful careers in Poland. Although they made contributions to Scottish liturgical repertoire and practice in the form of synagogue compositions, my primary focus in this article is on musical texts created outside the synagogue: a series of commercial recordings made in the early 1920s by Meyer Fomin; and a cantata composed in the mid-1930s by Isaac Hirshow. 
The texts are unique in the lives of these men, in that each of them mark a single musical moment that would, whether by circumstance or design, not be repeated. The texts therefore cut a diachronic slice through their cantorial careers, but at the same time can be understood syntagmatically as one part of a larger chain of events and meanings. It is my argument that these texts also capture a perspective that looks two ways at once- to the 'tradition' and history of Eastern Europe, and to the modernity of the West and the acculturation of an immigrant experience. The two texts speak to this moment of transition, simultaneously framing and problematizing discourses of authenticity as expressed through material cultural production.

As cultural historian Ben Highmore notes: "we have no existential access to, or contact with, the past... There is no choice but to work in a world of partial views". ${ }^{7}$ In building up a picture of these men's lives and work, I have drawn on multiple narratives-complementary sources that each offer different, partial aspects. Personal documents and photographs locate these men across social and cultural relations of kinship, employment and mobility. Family memories frame chronologies within contexts of memory, emotion and affect. ${ }^{8}$ Newspaper reports and advertisements, on the other hand, give an idea of the function of these men within their Jewish communities, and how they and others expressed their lineage and training.

Perhaps most eloquently, the two musical texts at the center of my article occupy a powerful space between the 'elsewhere' of Hirshow and Fomin's birth and development, and the 'here' of their adoptive Scotland, whilst also straddling parallel narratives of technology, musical learning, artistic resources, and the dialogue between religious and secular identities. Fundamental to this is a recognition of music as a social and discursive actor in the changing definitions of European Jewish identity in the nineteenth and twentieth centuries ${ }^{9}$ —a period that saw the emergence of the modern synagogue cantor, the development and consolidation of a 'Jewish' musical idiom and with it the movement of Jewish music from private to public space. ${ }^{10}$ Set against late nineteenth century movements, migrations and nationalisms, music increasingly mediated a dialectic between complementary/competing East-West discourses. Alongside their traditional role in Eastern Ashkenazi life, ${ }^{11}$ cantors began to develop a new and increasingly symbolic function amongst immigrant populations negotiating the at times conflicting identities of where they had come from and where they — and their children — now found themselves. Cantors and their music thus became metonymic of a real and known 
Eastern Europe for immigrant populations, but also metaphoric of an (often fondly) imagined Eastern Other to those for whom roots were often multiple.

These narratives are thus located within the tension between a home that is simultaneously, paradoxically, present and absent. As a result, the following texts also throw up pertinent questions around the troubled (and occasionally troubling) concept of authenticity—in music and in Jewishness. Jewish music scholar Jeffrey Summit makes an apparently simple link when he states that: "Issues of authenticity are especially important for diasporic communities. Both sounds and ritual objects connect members to community and history in ways both real and imagined”. ${ }^{12}$ We might, however, ruffle this smooth surface a little, and suggest that whilst sound undoubtedly connects people, community and history, the "authenticity" of cultural materials is often deeply contingent. ${ }^{13}$ A complex and shifting balance between the rooted and the hybrid is at the heart of what follows, an ambiguity directly related to the two men's particular admixture of Eastern European musical background and migration to Scotland. But far from undermining the credibility or significance of these texts, their straddling of simultaneous cultural spaces and subtle embrace of hybridity and dual-perspective is in fact what makes them meaningful, as hyphenated Scottish-Jewish identities. They show that authenticity can be layered and questioned through music, and that to reveal 'authenticity' as a construct does not diminish its power, but rather enriches and deepens easily-invoked and well-worn concepts of musical heritage and meaning. Ultimately, these texts illustrate that there are different ways to sound Jewish. And from the perspective of early twentieth century immigrant voices, such multiple soundings are inevitably nuanced in their dialogue between 'here' and 'there'.

\section{Cantor as star performer: Meyer Fomin}

Meyer Fomin was born in Vitebsk in 1888, the eldest of thirteen children. ${ }^{14}$ As a teenager, he toured Russia and Poland as a youthful star cantor. The phenomenon was not uncommon: holdings in YIVO and the Scottish Jewish Archives Centre include posters for performances by boys and young men such as Kalmele Weitz and Aaron Cina, often billed as 'wunderkind' or 'the Jewish Caruso'-a sobriquet that would be liberally applied to cantors, including both of the two best known, Yossele Rosenblatt and Gershon Sirota. This was part of a more general trend that saw many East European cantors leave their regular congregations for up to 
six months of the year in order to tour as peripatetic service leaders, increasing both their own prestige and that of their various host communities. The phenomenon continues today, symbiotically tying synagogues and cantors into national and international networks of exchange whilst avoiding the long-term financial commitments behind a salaried star performer. We might speculate that this extensive travel would likely have exposed the young Meyer to a wide range of musical influence and repertoire, instilling early on a tendency towards musical breadth and open-mindedness.

At some point in his youth, Fomin went to live with his grandfather in Riga. Grigori Fomin had been a soldier in the Tsar's army, and consequently had rights of residence unavailable to most Pale of Settlement Jews of the time. It is not clear how long Meyer remained with his grandfather in Riga, or what musical training he acquired there, but we can guess at the effects of the prewar city's Germanized, Western-facing perspective on the youthful Fomin's experience. And in the latter part of the first decade of the twentieth century he moved to Warsaw - at the time of Fomin's early adulthood one of the busy centers of European Jewish life. ${ }^{15}$ A multitude of synagogues ${ }^{16}$ and prayer houses, yeshivas, Yiddish and Hebrew newspapers and publishing houses, small and large Jewish businesses framed everyday existence. The Muranowska St synagogue, where it is likely that Fomin was cantor, was one of five on its street. With Gershon Sirota at Tłomackie St’s Great Synagogue and over 400 other clerics working in the city, ${ }^{17}$ Warsaw was also an international hub of both secular and sacred Jewish musical activity.

Although the exact date of his move to the city is unclear, Fomin was working in Warsaw by December 1910, when the Warsaw Yiddish newspaper Der Moment reports that the (now 22year-old) chazan would be leading a 30-strong choir as part of a Hanukah Evening for Talmud Torah children at 42 Piankne. More enlightening, perhaps, are the narratives that Fomin constructs for himself at this time, such as an advertisement that he took out in the same newspaper a month and a half later, offering services in music and voice tuition. Where his daily work was based around the musical life of the synagogue, this advertisement shows a considerably wider technical and theoretical musical skill set, citing Fomin's studies at the Warsaw Conservatory under a Professor Chodakowski. Josef Chodakowski (1850-1914) was a renowned opera performer of the late nineteenth century and by the time of Fomin's advertisement a well-known vocal pedagogue, working at the Conservatory between 1909 and 1913. Learning with Chodakowski would have exposed Fomin to repertoire such as Don 
Juan, La Traviata and Lift from the Seraglio, all of which the professor produced with Conservatory students. The Der Moment advertisement backs up this training by adding that the cantor is also a skilled improvisor of recitative. Although the text is mostly in Yiddish, the Cyrillic letters of Fomin's name and address symbolically inscribe the young cantor as a newer Russian-speaking arrival to the city, rather than a more established Polish-speaking Jew.

Reports of Fomin in Warsaw go quiet during the war. His Jewish Chronicle (JC) obituary suggests that he held the position of musical director in the Russian Army, although this needs much further investigation. Nevertheless, by the end of the decade, it seems that Meyer Fomin was a man of some standing in Warsaw Jewish society. In December 1920 he considered himself important enough to publish well wishes on the engagement of Louis Sirota ${ }^{18}$ and Judit Yissarov. And in 1921 Der Moment describes him as the "famous chazan Fomin”- the lack of a first name suggestive of a certain prestige. At this point in his career we also see an important link to the world of secular Yiddishkayt when, in 1919, the Warsaw Jewish cultural organization Hazmir announced its first concert of Folk Songs, performed by Meyer Fomin with piano accompaniment from Professor Karabkov and Sam Englander on violin. Hazmir had promoted literary, dramatic and musical evenings since before World War I, but the choice of Fomin to lead their first foray into folk song suggests that this still formed an important part of his repertoire, whilst also pointing to his inclusion in a Yiddish cultural circle well beyond the synagogue.

By the early 1920s, then, we see a successful cantor, of solid training and wide-ranging experience, forging his musical career in several directions simultaneously. But external pressures were also exerting themselves. Fomin's brothers-in-law were by this time successful fur dealers in Chicago, and plans had been laid for Meyer, his wife Bertha, and their son Abraham to join them-a move that would have entailed a radical career change. A stopover in Antwerp (their luggage already en route to Chicago) with the cantor Aaron Fuchsmann-who would himself work in Glasgow a decade later-initiated a chain of events that, as reported in the $J C$ of May $20^{\text {th }} 1921$, culminated in a members' meeting of Glasgow's South Portland Street Synagogue where, "Cantor M. Fomin of Warsaw was elected First Reader of the Congregation”. South Portland Street was the largest and most prestigious synagogue in Glasgow’s Gorbals. The Great Synagogue, as it was known, had been consecrated in 1901, and alongside the Jewish Institute next door would continue to function 
as a community and religious hub until the razing of the entire Gorbals tenement area —in favor of ill-fated tower blocks - in the 1960s, by which time most of the city's Jews had moved southwest to the suburbs.

At the time of Fomin's arrival, however, the Gorbals was a busy center of immigrant life, a place where Jews, Lithuanians, Irish and Italians (among others) negotiated cramped and heterogeneous community. Within this polyphony, Fomin's position as cantor of the Gorbals' main synagogue would have marked him out from the crowd. But it seems that he was keen to stamp his presence within UK Jewish life more generally-making, less than a year after his arrival, eight recordings for commercial distribution. The timing is pertinent. In Warsaw Meyer Fomin was clearly a known and respected figure of Jewish life, inspired by—but at the same time implicitly competing within — the Ashkenazi Jewish world's lively nerve center. In Glasgow the opposite was true: there was a smaller Jewish audience but also significantly less competition. And as a cantor trained and raised in Eastern Europe, Fomin's own relationship to Glasgow was of course very different. While in Warsaw he was one of a large number of Russian-born immigrants, in Glasgow his heritage and roots presented a community of diasporic Jews with more generalized symbols of the old country. At the same time his own new position at the Great Synagogue presented him as a top man in his (smaller) field. These records therefore stand as a moment of difference, of dual-perspective for Fomin: a leading UK cantor, endorsed by his credentials as a representative of Ashkenazic Eastern Europe.

Fomin made his eight recordings for the Winner Label in London some time between June and August 1922. ${ }^{19}$ A syndicate under the stewardship of Manchester industrialist James Hough, Winner (also The Winner) produced budget recordings from 1912 until 1935—partly as a response to large numbers of cheaper German imports. At a factory beside the Surrey Canal in Southeast London, performers would record in the top floor studio and have their recordings duplicated for distribution on the shop floor below. Exactly what led Meyer Fomin to the London studios is unclear. The Winner catalogue covered a wide musical spread-jazz, light classical, operatic and popular airs all feature prominently-but in more than two decades of recordings they only recorded three singers billed as "Hebrew" artists. ${ }^{20}$ More generally, however, Fomin would doubtless have been aware of the growing popularity of cantorial recordings and their effects on the careers of some of his Warsaw peers. Yet to face the challenge of radio, 'ethnic' recordings were attaining increasing importance as a 
transnational means of connection for immigrant communities, and synagogue cantors had been among the first singers to embrace this new channel of dissemination. Gershon Sirota first recorded for Victor in 1903 and had produced at least 40 sides by the outbreak of WWI. ${ }^{21}$ Another early cantorial recording star, Zawel Kwartin, was headhunted by Chester Abelowitz of Brunswick Records to record the first sides for the label's new 'foreign' (i.e. non-American) catalogue in July 1921. ${ }^{22}$ And high sales for Columbia in the 1920 s and 1930s would be instrumental in making an international name of Yossele Rosenblatt (18821933). ${ }^{23}$

As producers and promoters of the time were quick to note, these recordings were an important point of diasporic contact across shifting and expanding social and kinship networks of the late nineteenth and early twentieth centuries. Widespread listening technologies—able to reach in multiple directions over land and sea—were assuming increasing importance as a channel of collective cultural communication. Alongside newspapers (daily life), literature, poetry and song (symbolic life) and religious texts (spiritual life), "Hebrew" discs were affective actors in the "unisonance” ${ }^{24}$ of communities both real and imagined: "the echoed physical realization of the imagined community... [where] Nothing connects us all but imagined sound.” ${ }^{25}$ As Paul Gilroy has observed about black Atlantic networks of listening several decades later:

thanks to the reach and trans-local potency of phonographic technology, remote listening had acquired both social and political significance... hearing together had become connected to the possibility of thinking and acting together. ${ }^{26}$

More than simply vehicles of nostalgia, the very modernity of this transnational medium foregrounded its role as cultural connective tissue running between more established (Eastern) diasporic communities and newer (Western) immigrant groups.

Within this trans-locality, London had been one of the very first centers of cantorial recordings. On April $5^{\text {th }} 1899$ - three years before Sirota would cut his recording teeth-a certain Mr Fridkin recorded ten titles, followed on April $20^{\text {th }}$ and $21^{\text {st }}$ by a Mr Manné. ${ }^{27}$ The UK was also an early market. A 1902 JC advertisement from I Harris and Sons in Manchester offered a free list of Hebrew records to accompany sales of their machines, and in 1904 London’s Gramophone and Typewriter company announced the release of a "unique series of Jewish melodies comprising specimens of ancient and modern Chazonuth made 
popular by the celebrated Cantor Sirota of Wilna and his wonderful choir”. By 1908 the same newspaper's "From Far and Near” column was reporting that “Chazanuth by Phonograph” had "sprung up all over London”, ${ }^{28}$ and in 1910 "From the East End" cheerfully noted that the owner of a fish supper bar had installed a talking machine in order to boost trade, adding wryly: "Next we shall probably hear the sweet voice of the Chazan Sirota, and Fashion Street will certainly flock there for chips and edification." ${ }^{29}$ On November $26^{\text {th }} 1915$, columnist 'Sepharad' wrote, although with how much irony is genuinely unclear, that

a race whose ancestors were thrilled by the clang of the sistrum; enchanted by the guitar-like notes of the tambura, and carried away by the sheer beauty of the melodies of the asor-honoured parent of the dulcimer-now passes its nights in the cheerful company of-the gramophone.

Behind the banter, reports such as these provide an ongoing barometer with which to track the transitional public/private space that such recordings created and occupied. As Jeffrey Shandler notes, these "modular" technologies moved music that was liturgically tied to time and place into new relations of production and consumption. ${ }^{30}$ We can see this in a JC advertisement of August $4^{\text {th }} 1922$ (and repeated a month and a half later) that lists, in a small but bold rectangle of text, the titles and catalogue numbers of Fomin's eight Winner sides, proudly announcing them as "Specially recorded for the Jewish Community by the Rev. Meyer Fomin, Cantor, Glasgow Synagogue” (figure 1). Whether this “Jewish Community” is that of Glasgow, the UK, or the transnational diaspora, remains nicely ambiguous. Either way, however, this advertisement appears to be the JC's first since 1904 for a recording by a named cantor, and the first ever for a British-based cantor. Fomin's arrival in the UK-and more specifically his marking of it by making these recordings-is therefore pushed to the vanguard of internationalized networks, speaking to a transitory moment between the East of his training and the West of Jewish immigrant life, a point where the newly-arrived immigrant stakes his claim as a representative figure of both geographies simultaneously. A 1923 JC advertisement taken out by Young's of Glasgow makes this connection clear (figure 2), setting Fomin's Eastern designation as “Obercantor”, linked here with the Eastern Ashkenazi credentials of colleagues Sirota and Rosenblatt, directly alongside Glasgow, inscribed as his new place of work and also the business location of Young's, stockists of these gramophone records. With Fomin named first, and Fomin’s image accompanying the 
text, this advertisement acknowledges the UK—Scotland specifically—as an active part of modern internationalized cantorial society.

\section{INSERT FIGURE 1 HERE INSERT FIGURE 2 HERE}

If the British Winner label ties Fomin into UK networks of production, distribution and promotion, his choice of repertoire, composers and style unambiguously signify 'elsewhere'. We can get a sense of this 'elsewhere' by looking at the material Fomin chose to record. As with his 1919 Warsaw Hazmir concert, in 1922 his active repertoire still clearly encompassed both the secular and the sacred. For each of the four discs a liturgical melody is paired with a secular song (see figure 1), creating some memorable juxtapositions. Thus the well-known Yom Kippur prayer Avinu Malkeinu is matched by the comic Yiddish song A chazn af shabbes; Reisen and Bernstein's Tsum hemerl—a workers' song in the form of a poor cobbler's lament — meets the ode to spiritual continuity L'dor Vador; Russian poet Shmuel Frug's argument with God, Zamd un shtern, has as its B-side the Selichot plea Halbein Chatoeinu; ${ }^{31}$ and Berditchev Rebbe Levi Yitzchak’s A dudele (a "little song” to the Master of the Universe) is paired with Hu Eloheinu. ${ }^{32}$ The Avinu Malkeinu as recorded by Fomin is broadly similar to the better-known 'traditional' melody, ${ }^{33}$ but in fact shows far greater similarities with a version composed by Zawel Kwartin ${ }^{34}$ and recorded in New York for Brunswick in c.August 1921. Both renditions begin with an almost identical set of phrases, diverge somewhat in the middle (although still remaining close in mode and mood), and then come together again — more or less — at the end. Fomin's version is written out in a slightly longer form (the recording no doubt edited to fit the constraints of recordable time on a single 78 side) in his chazanut notebook brought with him from Warsaw. ${ }^{35}$ Although there is no clue from the notebook as to when Fomin wrote his Avinu Malkeinu, the close similarity between his version and Kwartin's points to several possibilities: either the dissemination of Kwartin's own version into prewar Eastern European cantorial networks - and its subsequent adaptation by other chazanim — or the presence of another, earlier, source from which both men took their opening and overall structure. Kwartin's autobiography puts him in Warsaw in 1907, which is a little earlier than the first evidence of Fomin’s arrival there, but both Kwartin and Fomin's extensive travel in the early part of the twentieth century makes the prospect of some sort of cross-fertilization of source melody highly likely. The fact that Kwartin's version was only recorded one year earlier suggests that both men may well have been laying implicit claim to their authorship of this particular version. 
The other side of the Avinu Malkeinu disc presents Fomin's rendition of A khazn af shabes. Although the actual composer of this song is now not known, it became widely disseminated through singer and collector Menachem Kipnis’ compilation 60 folkslider, first published in Warsaw in $1918 .{ }^{36}$ In the United States the song was first recorded by cantor Shloimele Rothstein (1920) and subsequently by cantors Mordechay Hershman (1923) and David Kusevitsky, as well as Al Jolson and Theo Bikel, among others. Two popular sheet music arrangements exist, both published in New York: the first by Leo Low (Hershman's arranger) in 1921, and another by William Scher, from 1932. The chronological proximity of Fomin's own recording to these others implies that, at this point, the song was part of a pool of repertoire that no one singer had yet stamped their own interpretation upon.

The text tells the story of a cantor who arrives in a small shtetl to lead the Sabbath prayers (as Fomin himself would have done as a younger man). The cantor's performance is evaluated by the town's three finest tradesmen — a tailor, a blacksmith and a coachman-in terms of their own trades. Thus the tailor finds that the cantor davens just as one makes a prick with a needle, whereas the coachman likens his singing to the crack of a whip. Particularly interesting is that while Fomin's version is clearly the same song as Hershman and Rothstein (the two closest recordings chronologically), it exhibits a far greater degree of variation and improvisation than these other two. Kipnis’ 1918 score (in which only the vocal line is given) gives as a performance marking 'fray retshitatirt mit khazonishn knak ["free recitative with cantorial snap”], and where Rothstein and Hershman stick fairly close to Kipnis and Low's original notation, Fomin interprets the suggestion towards idiosyncratic cantorial freedom further and far more dramatically. Whether for time constraints or aesthetics, his omission of the blacksmith verse allows him to fully savor the multiple embellishments and musical stretching that the subject matter self-consciously calls for. He also makes a point of giving the tailor and coachman different voices, something that neither Rothstein or Hershman (or even Al Jolson more than a decade later) attempted. Sacrificing his own strong tenor voice, Fomin's tailor sings in a wheedling, conniving sort of tone, whereas his coachman has a firm, no-nonsense delivery. Clearly at home with this material (and not the first time he has performed it), Fomin thus turns the song into a piece of Yiddish theatre, complete with stock shtetl characters, as well as the over-weening and ironically grandstanding chazan himself. 
Through his foregrounded connections to Kwartin, Sirota and his implicit contribution to the repertoire, Fomin locates his own musical voice clearly within Eastern European Ashkenazi tradition (including its popular conception as the most emotional and most 'Jewish' form). At the same time, these recordings and their accompanying promotion connect him directly to UK-based networks of production and consumption - in a way that was new for Britishbased cantors. Simultaneously inside and outside an idea of Eastern Ashkenazi Jewish musical repertoire and lineage, these discs position Fomin's narrative voice-musically and culturally - in a complex and sophisticated way, as both a standard-bearer of immigrant tradition (Avinu Malkeinu) and an occasionally ironic commentator upon it (khazn af shabes).

Meyer Fomin, however, made no more recordings after these Winner dates, although just why is no longer clear. Perhaps they did not alter his career in the way that he had hoped. Or perhaps the opposite is true, and with these eight sides he had made the statement that he wanted to and now felt happy to focus solely on synagogue and family life. What happened after this point is beyond my scope here, and instead I now want to offer a parallel set of prewar public-facing narratives through the work of a man who was five years Fomin's senior, and an equally important figure of Glasgow Jewish musical life.

\section{Cantor as art musician: Isaac Hirshow}

Isaac Hirshow was born Yitzak Gershov in Velizh, a small town to the Northeast of Vitebsk, in 1883. He was the eldest of four children. At the time, the town was home to one synagogue and seven prayer houses. ${ }^{37} \mathrm{~A}$ drawing of the synagogue from 1868 shows a largish structure of two wooden buildings, the main one marked by a dramatically rising roof. ${ }^{38}$ Two years before Isaac's birth, the young Abraham Cahan — who would later achieve fame in the US as a writer and newspaper editor-was assigned a teaching post in Velizh. Cahan recalled that the Velizh Jews that he came across were Lubavitchers, who to his secularist surprise welcomed him at their synagogue. In 1878, the town had seen the birth of Zisman Kiselgof, "resident musical ethnographer" 39 of the St Petersburg Society for Jewish Folk Music.

Kiselgof's father was a Velizh melamed, and it is not beyond the realms of possibility that he taught the young Isaac. If not under the melamed Kiselgof, it may be that Isaac studied at the Talmud Torah that had been established in the town in the early $1880 \mathrm{~s},{ }^{40}$ or-less likely-at the state Jewish school at which the young Cahan had briefly taught. From his own testimony five decades later, we know that the teenage Hirshow went to yeshiva, and indeed a Lubavitch yeshiva was established in Velizh in the mid-nineteenth century under Avraham 
Abba. It is, however, equally likely that Hirshow in fact attended yeshiva in Vitebsk.

Precisely where Isaac acquired his musical training is also unclear. Kiselgof, five years his senior, claimed to have had a small number of violin lessons from the town's klezmer violinist and pianist Meir Berson, known as Meir the Red (Meir Rizhiy in Russian, Mayer der Geller in Yiddish). ${ }^{41}$ Meir’s granddaughter described her grandfather as "a musician, a pianist and a Klezmer, who was often called upon to give command performances for visiting dignitaries." 42 If Meir Berson was indeed the town’s first-call musician for public events and instrument repairs, he was unlikely to have been the only one within travelling distance. The 1897 census for Vitebsk Gubernia puts the Jewish population at 5,982, almost fifty percent of the total population, and without doubt large enough to sustain several musicians and music teachers among them. Hirshow would also, of course, have received musical training as part of synagogue life, and through formal or informal means had acquired enough ability by his early teens to have graduated from meshoyrer [choirboy] to synagogue choirmaster. ${ }^{43}$

In his mid-teens, following the death of his mother, Hirshow-like Fomin-moved to Warsaw. In 1903, he began as a choirmaster at the Sinai Adas Yeshurun synagogue at 21 Świętojerska Street, graduating to chazan in $1905 .{ }^{44}$ Close to Nalewki, in the heart of Jewish Warsaw, Adas Yeshurun was known as the synagogue of musicians and was famous for its choir and cantors. Touring cantorial stars such as Moshe Koussevitsky led services there, and a 1905 photographic line-up of chazanim, choirmasters and boy singers testifies to a rich musical life within the synagogue walls. ${ }^{45}$ Alongside Head Cantor Moshe Zhornitsky and choirmaster/conductor Rothstein, we also find the young Menachem Kipnis a decade prior to his renown as a singer and Yiddish song collector (including, as we have seen, his 1918 folkslider collection, which included “A khazndl af shabes”), and a ten-year-old Henry Lefkovitsh, who in America would become a successful performer, arranger and conductor.

Newspaper reports over the following decade and a half show Hirshow increasingly tied in to the religious, social and musical life of Jewish Warsaw. In 1913, a siyum hasefer held at Zal Angelski is accompanied by a performance from the "famous 'Sinai' choir under the leadership of Chazan Y. Gershov”, accompanied by a twelve person orchestra. And in 1916 we find Hirshow, Sinai choir and “Ober Cantor” Aaron Fuchsmann leading a Hanukah celebration on behalf of the Watchmaker's Union. An advertisement in Der Moment in 1917 offers the services of "dirigent [conductor] Gershov...from 3 till 6 [in] piano and general 
music tuition” at Hirshow’s family home on Leszna St (now Solidarinosc Avenue). It is likely that Isaac Hirshow and Meyer Fomin knew each other through shared connections in the populous but close-knit circles of Nalewki religious life. As we learn from newspaper reports such as those above, Aaron Fuchsmann worked at the same synagogue as Hirshow, with Hirshow often listed as choirmaster to Fuchsmann's chazan. At the same time several of Meyer Fomin’s music anthologies bear inscriptions from his “very good friend” cantor Aaron Fuchsmann. ${ }^{46}$ And similar overlapping relationships within Warsaw cantorial networks can be seen by several of the same compositions found in Hirshow and Fomin's notebooks, where identical notation suggests either direct transmission from one chazan to the other, or else both men taking their repertoire from the same source. ${ }^{47}$

Perhaps, however, Hirshow also felt himself somewhat in the shadow of 'ober' cantors. Certainly we do not in these years see the same sort of acclaim that attached to Fomin and Fuchsmann. Hirshow never appears in newspaper reports as the main event, but rather as leading the choir, an important but implicitly less prestigious role than the cantor it is accompanying. A multitude of Warsaw synagogues and cantors would have meant opportunity but also heavy competition. Possibly for this reason, in 1918 Hirshow accepted an invitation to become chief cantor and choirmaster of Łomża’s main synagogue-a post that offered the chance to be at the center of the musical-religious life of a community, rather than one amongst many. He clearly distinguished himself there-a 1921 letter of recommendation from renowned Łomża scholar Yehuda Leib Gordin notes his “excellent character", "powerful and melodious" voice and compositions that have "touched the hearts" of the congregation. His time in Łomża also provides the first evidence we have of Isaac (for the first time calling himself Hirshow rather than Girshow, a name change possibly suggestive of a renewed sense of self) offering a fully public face to his musical identity, in the form of concert programmes from April 1921. If Hirshow had given recitals in Warsaw, these do not seem to have been advertised publicly. By contrast, the two Łomża concerts point to an artist at home across a variety of performance styles and musical genres. The first half of each concert—-titled “religious”-includes Hirshow’s own compositions Di Melekh and Mizmor Shir Hanukah. ${ }^{48}$ The second part—“classical and folk songs”-puts Hirshow’s own arrangements of texts by Sholom Aleichem, Shmuel Frug and Hayim Nachman Bialik alongside Mendelssohn, Rubinstein and Beethoven, as well as the Yiddish song Vayl ikh bin a yid, which twenty years later would acquire new resonance as a song of the Łódź ghetto. 
Whilst Meyer Fomin's motivation to sidestep a proposed alternative life as a Chicago fur trader is easy to grasp, we can only speculate at Hirshow's reasons for leaving what seems to have been a well-respected and prestigious post in Łomża. The massive interwar changes affecting Polish Jewish life cannot be ignored, as well as increasing political foment. ${ }^{49}$ We do have some hint of Hirshow's mixed feelings towards the lands of his birth and early life. Speaking in 1950, he described how in the "vast and rich" country of his birth, "the Jew was cast into a corner like into a dustbin—in want, in misery, in darkness and fear...the last drop of his blood drained, the marrow of his bones dried up." ${ }^{50}$ Whatever prompted his move, the process was made possible through previous similar journeys and the transnational links generated therein. Isaac Goldman (originally Gzshibovitsh) had come to Tredegar from Łomża in the very early twentieth century and moved up to Glasgow through the influence of his wife’s sister's chazan husband, Rev Bloch. It was Goldman’s subsequent continued contact with the Łomża rabbinate that led to Hirshow moving to the Gorbals Chevra Kadisha synagogue in 1922.

Like Fomin, then, Hirshow was working in the Gorbals, the heart of Glasgow's newlyarrived Jewish community, by 1922. Immigrant life was noisy and crowded. Gorbals boy Ralph Glasser recalled that: "Rats and mice moved about freely, seeming to share the accommodation with us grudgingly, as if we were the intruders and they the rightful occupiers.” Whilst deprivation and ghettoization would likely have been familiar, Hirshow was disarmingly honest about what he felt were strong contrasts between his native and his new home:

My luggage I brought with me consisted of material poverty and spiritual wealth...It did not take me long to realise that the Jewish life here was a world turned upside down...All values reversed....and it became clear to me that material wealth and spiritual poverty would serve me better. ${ }^{51}$

But as mentioned at the start, the Gorbals was not the only focal point of Jewish life in the city. At the western end of the city center, a few streets away from where Charles Rennie Macintosh would later design the Glasgow School of Art, was Garnethill synagogue. Garnethill minute books held in the Scottish Jewish Archives Centre note that in October 1925 the synagogue Secretary had asked Rev. E. Spero, recently retired chazan of London's Central Synagogue, to recommend a suitable chazan for Garnethill, but as yet no answer had 
been forthcoming. Minutes from the same month report "Rev. I. Hirshow of Oxford St. Syn [Chevra Kadisha] invited to conduct services on Fri night and Sat morning Oct 16 \& 17’. Following this invitation, and subsequent interview, an Extraordinary General Meeting of the synagogue council on November $8^{\text {th }}$ unanimously agreed to appoint Hirshow as Reader to the congregation.

Given his orthodox Velizh upbringing, Isaac's decision to move smartly across the river to the city's older and anglicized community is perhaps surprising. And speaking in 1950, Hirshow good-naturedly described his own ambivalence about the move.

One of my advisers tried to persuade me against taking this most risky step. 'Think twice, Mr Hirshow. What sort of Yidden are there in Garnethill anyway? They cannot even speak Yiddish!’ A second said, 'You had better pack up your Chazanut. Garnethill doesn't need a Chazan.' A third said, 'You will have to shave off your beard., 52

The beard anecdote has passed into Glasgow Jewish legend, but beneath the gentle digs, it is possible that the very things which appalled Hirshow's friends might have been amongst those that appealed to him: the rise in status and opportunity to become part of the Glasgow Jewish establishment (as opposed to the Jewish ghetto), plus of course a substantial increase in wages. ${ }^{53}$

We can also frame Hirshow's move a little more sociologically, as mediating a narrative space between the formalized integration processes of nineteenth and twentieth century Anglo-Jewry and a lingering sense of Eastern European 'authenticity'. From the early part of the twentieth century onwards, Garnethill had seen increasing numbers of recent Eastern European immigrants join its congregation, and so it is perhaps inevitable that this would be reflected in their choice of cantor-perhaps most of all in their choice of cantor, given the acknowledged role of music as an expression of Jewishness ${ }^{54}$ and Jewish tradition. For whilst Fomin and Hirshow had been Russian Jewish immigrants in Jewish Warsaw, in Glasgow they were symbolic of both a real alter heym [old country] for many of their congregation, and an imagined Jewish Eastern Europe for others. Scottish Jewish historian Kenneth Collins writes:

For an increasingly secularised membership, though reared on the traditions of Eastern Europe, it was the vocal ability of the chazan on the High Holy Days, rather than the 
scholarship of the rabbi, which reconnected the immigrant Jew with the traditions from which he was being estranged. ${ }^{55}$

Like Meyer Fomin, Hirshow's musical life straddled the East of his birth and schooling and the West of his physical migration. And also like Fomin, the musical narratives that Isaac Hirshow constructed for himself went beyond the synagogue. Those who knew Isaac spoke of him as something of a polymath, proficient in engineering and mathematics along with music and Jewish learning. In 1926, only one year after moving to Garnethill synagogue, he entered the University of Glasgow to study for a Masters in Arts. His subjects included Moral Philosophy, German, Political Economy, and Logic and Metaphysics. At this point, the university offered no degree in Music, so it is possible that Hirshow's intention was in fact to further his studies outside of his chosen career. However, in 1928 the Gardiner brothers endowed the university with a fund of $£ 20,000$ for the provision of a Professorship in Music, a Chair that led in 1932 to the inauguration of a Bachelor in Music. ${ }^{56}$ Hirshow enrolled on this degree that same year, ${ }^{57}$ and on October $15^{\text {th }} 1938$ graduated as the University of Glasgow’s first Bachelor of Music. ${ }^{58}$ His degree included classes in counterpoint, orchestration, music history, acoustics and harmony, and the core syllabus covered English Tudor to Wagner.

Hirshow's completion of his BMus roughly bisects his career at Garnethill. There is no evidence that gaining a degree materially altered his situation there, nor is there any sign that he intended to use his qualification to secure an alternative position. ${ }^{59}$ Consequently, we can interpret his decision to enter the academy as a personal one, a desire to further his musical understanding but also perhaps find a way of reconciling his Jewish musical voice within a more classical framework. We can see this in the final (and only surviving) piece that Hirshow produced for his music degree: a cantata fully scored for solo voices, chorus and chamber orchestra, entitled "The Hope of Israel". The cantata bases its four vocal movements on the Min Hametzar from Psalm 118. ${ }^{60}$ Musically, it is a sophisticated blend of Jewish liturgical modal musical language and Western classical choral tradition-a work of rich contrapuntal and imitative textures, at the same time moving freely through small motifs and larger themes that in their melodic and rhythmic arc nod strongly towards a sense of musical Jewishness. The work’s complexity and scope far exceeds what one might expect at undergraduate level (not so surprising, given that Hirshow had been a professional musician 
for thirty years by the time of its composition), representing a valuable and virtually unknown contribution to Jewish art music. ${ }^{61}$

Most noteworthy about Hirshow's choice and treatment of material for this piece is how it exhibits a clear intention to foreground, rather than sideline, Jewishness as a part of musical identity. Within the academic brief and his representative position as the university’s first music graduate, Hirshow's self-identity as a Jewish composer is clear and confident. Thus although the cantata was composed to fulfil the formal requirements of a university exam, if we place it in a wider context we can see that the work stands at the intersection of powerful temporal and geographic forces-like its composer delicately poised between dialogues of East/West, past/present and insider/outsider. The intertextual title itself, with its unavoidable reference to Hatikvah [the hope]—adopted as the Zionist anthem since the first Congress of 1897-looks in several directions simultaneously: towards land as both historical homeland and at the same time a modern state yet to come into existence; but also encompassing Israel as a people, their future hopes and inevitably the increasing persecution of Jews further East (from where Isaac himself had come and where the majority of his family remained, soon to perish). The piece is therefore simultaneously a musical narrative and a social-religious one, these two spheres overlapping within the musical language itself. With his importing of Jewish liturgical modes and text into a Western art music framework, Hirshow is implicitly making the case for a national music - in this case for a people who did not yet have a nation state. Indeed, the presence of a title at all (Hirshow is unique among those who have set the text in opting for an additional title, rather than simply "Min Hametzar") lends the work a specifically programmatic quality, an explicit inscription of extra-musical meaning.

\section{INSERT FIGURE 3 HERE}

Philip Bohlman writes that nineteenth century European constructions of Jewish music saw it "increasingly [become] a music in which the identity of selfness was largely a product of difference"-Jewish specificity expressed in relation to both European romanticism and an increasingly global interface for Jewish musical practice. ${ }^{62}$ Hirshow was, of course, not alone in his quest towards a sense of musical nationalism. In this he is connected to a wider movement that takes in composers such as Bartók, Janáček, Sibelius and Vaughan Williams in its search for distinctive musical sources rooted in folk and vernacular idioms, framed by the formal structures and conventions of the classical canon. Within Jewish music this had its strongest expression in St Petersburg's Society for Jewish Folk Music, formed in 1908-a 
dynamic and far from unified synthesis of newly emancipated younger Jewish musical scholars and the city's burgeoning middle-class intelligentsia. Partly prompted by the renewed traction that Wagner's formulations of Judaism in music were gaining in early twentieth century Russia, the Society promoted a newly-energized, secular musical space that aimed to move away from the Orientalism that had hitherto accompanied Jewish idioms within the concert hall, driving instead towards the sophisticated inclusion of a wide range of Jewish material (including klezmer, Hasidic nigunim and liturgical prayers), into a language of musical nationalism both Jewish and Russian. ${ }^{63}$ Further west, a forceful tension between universality and difference within Jewish art music is found in the work of Swiss composer Ernest Bloch (1880-1959). Born only three years before Hirshow, Bloch also emigrated-to America - in his late thirties, and both men also trained in cities that were not their native ones. Hirshow does not seem to have shared Bloch's painful sense of a lack of homeland, but at the same time the dynamic and mobile relationships that frame his Cantata offer an intriguing parallel to Malcolm Miller's assessment that 'for Bloch the search for a true artistic homeland was at the heart of his identity. 64

The similarities, however, only extend so far. Bloch and the St Petersburg School were secular musicians ${ }^{65}$ and were not writing their music as undergraduate students. Hirshow's adherence to materials outside the Western classical canon is particularly striking in relation to the determinedly Anglo- and German-centric pedagogical thrust of the new Glasgow BMus degree, where recommended course texts included E. Walker's History of Music in England and E.H. Fellowes’ The English Madrigal School, accompanying an almost exclusively Germanic list of composers that began with Bach and concluded with Wagner. ${ }^{66}$ Within the context of this newly-inaugurated yet wholly conventional syllabus, Hirshow's submission — the first one that the university had ever seen-is a bold choice both in subject matter and musical resources, specifically Jewish whilst at the same time rooted in a long classical and cantorial tradition of Psalm settings.

Unlike much of the Ashkenazi liturgy, Hallel is not linked to particular melodic or modal material, and thus, writes Neil Levin, "actually follows a tradition, established centuries earlier, of free musical expression according to contemporaneous idioms and styles.”67 More directly, Sholom Kalib posits a direct link between certain texts and an increased compositional complexity, suggesting that a particularly Eastern Ashkenazic freedom with nusach meant that "the texts that were emphasized to express the sentiments vital to the 
Eastern European synagogal community offered greater possibilities of musical depth, due to the length of the texts themselves as well as the accepted approaches in the East to chazanic and choral treatments." ${ }^{68}$ One result of this, he claims, was the production of a large amount of concert recitatives and choral compositions on certain staple texts, Min Hametzar among them. Composers Avraham Dunajewski (1843-1911) and Leo Low (1878-1960) both produced settings, and the text continues to inspire contemporary interpretations that range from hip Jewish pop (Neshamah Carlebach) to contemporary Western art music (Ralph Schlossberg).

In his blending of liturgical form and nineteenth-century classicism, Hirshow's most obvious predecessor is French composer Fromental Halévy (1799-1862), who had himself played a part in European constructions of Jewishness-in-music with his 1835 opera La Juive, one of the enduring successes of the nineteenth-century operatic stage. ${ }^{69}$ Halévy's setting-perhaps the best known-was commissioned by Samuel Naumbourg, newly-appointed chazan of the Paris Great Synagogue, for inclusion in his 1847 Zemirot Yisrael synagogue music collection but continues also to appear as concert repertoire. Hirshow's, on the other hand, was part of a degree portfolio and did not receive its first performance until eight years after his death. ${ }^{70}$ Although we cannot know for sure, it is unlikely that Hirshow would ever have intended his cantata (in modified form) to form part of actual synagogue service: its forces are too broad (Halévy’s has no orchestra), its scope too ambitious. Hirshow, however, shares with Halévy a strong interplay between soloist and choir-the psalm's structure lending itself well to a musical setting rooted in liturgical traditions of call and response. This structure is reinforced — or perhaps determined by — the text's oscillation between positive and negative, and both composers use tonal resources to characterize an overall semiotic trajectory from the darkness and narrowness of "Min hametzar" ["In distress”] to the final daylight and exultation of "nagilah venismecha” [“exult and rejoice”]. Hirshow's setting also mines this symbolic journey more structurally. The two lowest solo voices (bass and tenor) appear in the first - $\mathrm{C}$ minor — movement only, followed by a skittering second movement that echoes the text's “multitude of nations”, pressing in on all sides. The two higher solo voices (alto and soprano) head a reflective, more penitent third movement, leading into a finale that takes a series of increasingly jubilant rising motifs through all voices ${ }^{71}$ - the textual depth-to-surface thematic convincingly finding its musical equivalent. And where Halévy’s setting begins briskly, Hirshow's opens on a far darker and somberly reflective mood, reserving its allegro maestoso for the final joyful movement, now resolutely in E flat, the relative major of the 
opening C minor movement. Through his skilful combining of the scholarly and the devotional into dynamic musical-cultural relationships, Hirshow's own dual perspective finds expressive form. He thus performs a neat balancing act that tames the excesses of Eastern Ashkenazi chazanut within Western classical choral structures, tonal harmony and classical form (imitation, canon, repetition and variation) paralleled at the same time by an implicitly subversive importing of Jewish Otherness into the conservative halls of academia. $^{72}$

\section{INSERT FIGURES 4 \& 5 (TOGETHER IF POSSIBLE) HERE}

\section{Conclusion}

With the gradual diminishing of synagogue congregations and revenue, and no full-time cantors for more than a decade, liturgical music in Scotland is unlikely to again see the kind of dedicated original music that marked out the careers of Hirshow, Fomin, and others like them. Increasing overlap of rabbinical and cantorial roles has promoted an inevitable decrease in bespoke repertoire, accompanied by a greater reliance on trusted and widespread sources such as the Blue Book. ${ }^{73}$ With the closure of South Portland Street in 1974, none of Meyer Fomin’s music remains in use. And indeed, his synagogue gone and the community now elsewhere, Fomin himself exists in a somewhat vague, liminal space of Scottish Jewish memory. We might argue that the heavy Eastern European aesthetic that was his legacy is now less relevant to Scottish Jewish musical identity. It is also possible that Fomin's synagogue compositions have been eclipsed by the prolific Ernest Levy, cantor of Giffnock synagogue (where many of the Gorbals second generation ended up). Isaac Hirshow, on the other hand, has left more traces. Despite reduced numbers, Garnethill synagogue remains active, and Hirshow and his longtime Minister colleague Dr IK Cosgrove exist symbolically as representatives of a sort of golden age of Glasgow Jewry. ${ }^{74}$ Hirshow's music, too, can still be heard. Part-time chazan and choirmaster Eddie Binnie curates a deliberately wide and inclusive repertoire that is both an indication of a broader postwar move away from Eastern Ashkenazi influence and a reflection of his contemporary congregation's diverse origins. But at the time of writing, he and his choir retain Hirshow's beautiful Hashkiveinu and Uvashofar Gadol in regular service use. ${ }^{75}$

With both these texts, the Winner recordings and the university cantata, Meyer Fomin and Isaac Hirshow positioned their own musical and cultural narrative voice transnationally- 
simultaneously within and without an Eastern European musical perspective, yet tied in parallel to their adoptive Scotland. Neither event would be repeated. Fomin made no more recordings after these Winner dates, and Hirshow never produced another 'classical' piece. Perhaps they got them out of their system, or perhaps these works speak to a particular point in Scottish Jewish history that was as transient as it was significant. The Winner discs and the BMus cantata — and indeed the lives and work of these men more generally_articulate a historically specific moment at the intersection of immigration, assimilation, Eastern and Western musical and social narratives. Meyer Fomin’s integration of Eastern Ashkenazi style and repertoire into British networks of commodification and dissemination, and Isaac Hirshow's importing of Hebrew texts and semiotically Othered musical language into British establishment models of education and recognition both stand as unique and vital contributions to Scottish Jewish cultural expression. But more than this, they reveal the sounds of Jewishness to be multiple and fluid, and that these different soundings are each as meaningful as they are contingent.

\section{References}

Anderson, Benedict. Imagined Communities. New York: Verso, 2006.

Bohlman, Philip. “The Worlds of the European Jewish Cantorate”. In Echo der Vielfalt, Echoes of Diversity: traditionelle Musik von Minderheiten/ethnischen Gruppen, Traditional Music of Ethnic Groups/Minorities, edited by Ursula Hemetek and Emil Lubej, 49-64. Vienna: Böhlau Verlag, 1996.

Bohlman, Philip. "Introduction: The Transcendent Moment of Jewish Modernism” in Jewish Musical Modernism, Old and New, edited by Philip V. Bohlman, 1-30. Chicago: University of Chicago Press, 2008.

Braber, Ben. Jews in Glasgow 1879-1939: Immigration and Integration. Edgware: Valentine Mitchell, 2007.

Collins, Kenneth. The Jewish Experience in Scotland's Jews: From Immigration to Integration. Glasgow: Scottish Jewish Archives Centre, 2016. 
Conway, David. Jewry in Music: Entry to the Profession from the Enlightenment to Richard Wagner. Cambridge: Cambridge University Press, 2011.

Gibbon, Lewis Grassic. “Glasgow” in Smeddun: A Lewis Grassic Gibbon Anthology. Edinburgh: Canongate, 2001 [orig. 1934].

Gilroy, Paul. "Between the Blues and the Blues Dance. Some Soundscapes of the Black Atlantic.” In The Auditory Culture Reader, edited by Michael Bull and Les Back, 381-395. Oxford: Berg, 2003.

Highmore, Ben. Michel de Certeau: Analyzing Culture. London: Continuum, 2006.

Hirshberg, Jehoash. Music in the Jewish Community of Palestine, 1880-1948: A Social History. Oxford: Clarendon Press, 1995.

Idelsohn 1932. Thesaurus of Hebrew Melodies (vol 8, Hasidic). [Citation to follow]. Idelsohn, Abraham. Zvi. Jewish Music: Its Historical Development. Tudor Publishing Company: New York, 1944.

Jordan, Ruth. Fromental Halévy: His Life and Music, 1799-1862. London: Kahn \& Averill, 1994.

Kalib, Sholom. Musical Traditions of the East European Synagogue, Volume 1. Syracuse: Syracuse University Press, 2002.

Karlo, Adrian and Badrock, Arthur. Numerical Listing of Edison Bell Winner Records. Bournemouth: E. Bayly, 1989.

Kligman, Mark. "Re-establishing a 'Jewish Spirit' in American Synagogue Music: The Music of A.W. Binder.” In The Art of Being Jewish in Modern Times, edited by Barbara Kirshenblatt- Gimblett and Jonathan Karp. Philadelphia: University of Pennsylvania Press, 2008.

Kipnis, Menachem. 60 folkslider fun Zimra Seligfeld un M Kipnis kontsert repertuar, gezamelt durkh M Kipnis. Warsaw: Farlag A. Gitlin, 1930. 
Kiselgof, Zinoviy. My Autobiography. 1935. Institute of Manuscripts of Vernadsky National Library of Ukraine. http://audio.ipri.kiev.ua/aboutCD23.html. Accessed January 30 2019.

Knapp, Alexander. “From Geneva to New York: Radical Changes in Ernest Bloch's View of Himself as a 'Jewish Composer' during his Twenties and Thirties.” In Ernest Bloch Studies, edited by Alexander Knapp and Norman Solomon. Cambridge: Cambridge University Press, 2016.

Kwartin, Khazzan Zawel (Zevulon). Mayn Lebn. Philadelphia-New York: S. Kwartin Publishing Committee, 1952.

Laird, Ross. Brunswick Records A Discography of Recordings, 1916-1931. Volume 1: New York Sessions, 1916-1926. Westport: Greenwood Press, 2001.

Levin, Neil. “Introduction to Volume 7: Masterworks of Prayer.” Milken Archive of Jewish Music. https://www.milkenarchive.org/articles/view/introduction-to-volume-7/. Accessed January $30^{\text {th }} 2019$.

Loeffler, James. The Most Musical Nation: Jews and Culture in the Late Russian Empire. New Haven: Yale University Press, 2010.

Löwe, Heinz-Dietrich. “From charity to social policy: The emergence of Jewish 'self-help’ organizations in imperial Russia, 1800-1914.” East European Jewish Affairs 27, no. 2 (1997), 53-75.

Marmorstein, Gary. The Label: The Story of Columbia Records. New York: Thunder’s Mouth Press, 2007.

Marovitz, Sanford E. Abraham Cahan. New York: Tyrane, 1996.

Miller Evelyn Zarchy. http://zichronnote.sfbajgs.org/ZichronNote-1999-5-8.pdf., 1995. Accessed January 30 2019.

Miller, Malcolm. “Bloch, Wagner and Creativity: Refutation and Vindication.” In Ernest Bloch Studies, edited by Alexander Knapp and Norman Solomon. Cambridge: Cambridge University Press, 2016. 
Regev, Motti \& Seroussi, Edwin. Popular Music and National Culture in Israel. Berkeley: University of California Press, 2004.

Shandler, Jeffrey. Jews, God and Videotape: Religion and Media in America. New York: New York University Press, 2009.

Shepherd, John. "Music and Social Categories.” In The Cultural Study of Music, a Critical Introduction, edited by Martin Clayton, Trevor Herbert and Richard Middleton. New York: Routledge, 2003.

Slobin, Mark. Chosen Voices: The Story of the American Cantorate. Urbana: University of Illinois Press, 1989.

Spector, Shmuel and Wigoder, Geoffrey. "Velizh.” In The Encyclopedia of Jewish Life Before and During the Holocaust, Volume 3. New York: New York University Press, 2001.

Summit, Jeffrey A. Singing God's Words: The Performance of Biblical Chant in Contemporary Judaism. Oxford: Oxford University Press, 2016

Summit, Jeffrey A. The Lord's Song in a Strange Land: Music and Identity in Contemporary Jewish Worship. Oxford: Oxford University Press, 2003.

Wróbel, Piotr. “Jewish Warsaw before the First World War.” POLIN Studies in Polish Jewry 3 (1988): 156-187.

Zemel, Carol. “Diasporic Values in Contemporary Art: Kitaj, Katchor, Frenkel.” In The Art of Being Jewish in Modern Times, edited by Barbara Kirshenblatt-Gimblett and Jonathan Karp. Philadelphia: University of Pennsylvania Press, 2008.

\footnotetext{
${ }^{1}$ Gibbon, “Glasgow,” 106.

2 The similarity was not accidental: London Jewish architect Nathan Joseph was involved in the design of both buildings. See Braber, Jews, 143. See also Parry-Jones (this volume).

${ }^{3}$ Zemel, "Diasporic Values," 181.

${ }^{4}$ See Hirshberg Music; Regev \& Serroussi Popular Music.

${ }^{5}$ Other notable long-term residents include Herman Heisz (1909-1995) and Ernest Levy (1925-2009) of Langside and Giffnock synagogues respectively.

${ }^{6}$ A trajectory well illustrated by the transnational careers of Aaron Fuchsmann (Warsaw-Antwerp-GlasgowLondon), Charles Lowy (Munich-Budapest-Glasgow-London) and Zvi Finkelstein (Petach Tikva-GlasgowLondon).

${ }^{7}$ Highmore, Analysing, 9.
} 
${ }^{8}$ Alongside documents, photographs, family histories and memories, Isaac Hirshow's granddaughter Adèle Stephens and Meyer Fomin's granddaughter Marilyn Freedland have offered a great deal of encouragement and support, for which I am very grateful.

${ }^{9}$ Bohlman, "Introduction," 3.

${ }^{10}$ Bohlman, “The Worlds,” 52.

${ }^{11}$ See for example cantor Zawel Kwartin (1874-1953) on his early experience in the Galician town of Yaroslav: "Burdened Jews, who fight tooth and nail all week for a little living...see the hazzan as a true spokesman for their buried feelings" (cited in Slobin, Chosen Voices, 16.)

12 Summit, Singing, 46.

${ }^{13}$ John Shepherd posits "the distinct possibility that musical life has always been characterized by complex patters of cross-fertilization and cultural hybridity, and that notions of organic rootedness and 'authenticity' are largely mythical” (“Music," 75).

${ }^{14}$ Biographical detail for Fomin comes from the recollections of his son Allan (1917-2011) and granddaughter Marilyn Freedland (b.1948).

${ }^{15}$ Wrobel (“Jewish Warsaw,” 162) notes that "Litvaks—-Russian Jews’ or 'Jews from Lithuania'” had been moving to Warsaw for some time. Rights of residence were relatively easy, and military service was less harsh in "the last great city of the Tsarist Empire."

${ }^{16}$ Wrobel ("Jewish Warsaw”, 159) puts the number of synagogues at over 200 by 1871.

${ }^{17}$ Ibid., 170.

${ }^{18}$ Louis Sirota may well have been a relative of cantor Gershon Sirota.

${ }^{19}$ Information about Fomin's recordings and the Winner label from Karlo and Badrock, Numerical Listing.

${ }^{20}$ The other two sessions were: Rev I Tkatz (or possibly I T Katz) in 1916 and the Rev. N. Halter-with J.G.

Halter at the organ-in 1930.

${ }^{21}$ Discography of American Historical Recordings:

http://victor.library.ucsb.edu/index.php/talent/detail/54446/Sirota_Gershon_vocalist_tenor_vocal. (accessed January $30^{\text {th }}$ 2019). A 1910 JC interview noted that although Sirota had opted to remain at Tłomackie Stwhich by then was issuing tickets in order to limit his weekly audiences to five thousand-the "offers from other congregations came to him largely as a result of his singing into the gramophone, which enabled his gifts to be appreciated far and wide” (JC July $\left.8^{\text {th }}, 1910\right)$.

${ }^{22}$ Laird, Brunswick, 5.

${ }^{23}$ See Marmorstein, The Label, 45. Perhaps the most widely-known prewar cantor, Rosenblatt emigrated to the US in 1912. He appeared alongside Al Jolson in 1927's The Jazz Singer.

${ }^{24}$ Anderson, Imagined Communities, 145.

${ }^{25}$ Ibid.

${ }^{26}$ Gilroy, "Between,” 385.

${ }^{27}$ Information from Jewish discography historian Michael Aylward, who has compiled a list of roughly 135 sides recorded in London between 1899 and 1923 (personal communication, April 16 $6^{\text {th }}$ 2018).

${ }^{28}$ JC March 13 ${ }^{\text {th }}$, 1908: "From Far and Near": "The Russo-Jewish melodies are all the rage at these establishments in the East End, and the patronage accorded them is surprisingly extensive."

${ }^{29}$ JC March $4^{\text {th }}$, 1910: "From the East End” (“trade follows the gramphone”).

${ }^{30}$ Shandler, Jews, 24.

${ }^{31}$ Not uncommonly for the time, this was mis-translated on the record label as "Half our sins" —Winner labelwriters mistaking the Yiddish halb [half] for the Hebrew halbein [whiten]. I am very grateful to Fomin's granddaughter Marilyn Freedland for lending me her cassette copy of Avinu Malkeinu/A khazn af shabes and to Julian Futter for sending me a digital recording of his copy of Halbein Chatoeinu along with scans of the Zamd un shtern and Halbein Chatoeinu labels.

32 The two songs on this last disc (3677) are in a sense the most compatible, both representing a penitent address to the Almightly. As yet, I have been unable to track down a copy of this recording, so it is unclear which version of $\mathrm{Hu}$ Eloheinu Fomin sang.

${ }^{33}$ Also referred to as the 'Hasidic' version, this appears to have first been published by AZ Idelsohn in 1932.

See http://web.nli.org.il/sites/NLI/English/music/music-stories/Pages/Avinu-Malkeinu.aspx (accessed January $30^{\text {th }}$ 2019). Not to be confused with the post-war setting written by Max Janowski and recorded by Jan Peerce, Barbara Streisand and others.

${ }^{34}$ Born in Ukraine, Kwartin held posts in Vienna, St Petersburg and Budapest before emigrating to the United States in 1919, where he worked as head cantor of the Brooklyn Temple Emanuel. He settled in Israel in 1926, continuing to record and concertize widely.

35 These notebooks were given by Fomin’s grandson Lenny Wolfe to the National Library of Israel. I am very grateful to both Lenny and Gila Flam at National Library of Israel for allowing me access to these materials. ${ }^{36}$ Along with Kipnis’ subsequent 192580 folkslider, these combined collections contain a wealth of still wellknown Yiddish folksong repertoire, such as der Rebbe Elimelech, di Goldene Pave and Yoshke fort avek. 
${ }^{37}$ Spector and Wigoder, "Velizh,” 1328.

${ }^{38}$ See https://radzima.org/eng/object/synagoge-7391.html. Accessed January 30 2019.

${ }^{39}$ Loeffler, The Most 161.

${ }^{40}$ Löwe, "From Charity," 68.

${ }^{41}$ See Kiselgof, Autobiography, 1.

${ }^{42}$ From an article written by Berson’s granddaughter, Evelyn Zarchy Miller, in 1995:

http://zichronnote.sfbajgs.org/ZichronNote-1999-5-8.pdf. Accessed January 30 2019.

${ }^{43}$ According to the JC (December $29^{\text {th }} 1950$ ), he joined the choir aged ten and became choirmaster at fourteen.

${ }^{44}$ See https://sztetl.org.pl/en/towns/w/18-warsaw/112-synagogues-prayer-houses-and-others/89652-sinai-adasyeshurun-synagogue-warsaw. Accessed January 30 2019.

${ }^{45}$ Published in New York's Forverts Yiddish newspaper after the Second World War under the heading

"Historic Picture from Warsaw of Long Ago".

${ }^{46}$ These anthologies are held in Edinburgh Central Library archives as part of a larger collection belonging to cantor Ernest Levy (donated by Ernest's daughter Judy). As noted previously, Fomin and family stayed with Fuchsmann partway along their aborted journey to Chicago.

${ }^{47}$ Like Fomin, Hirshow's handwritten notebooks are held in the Music Department of the National Library of Israel. Again, thanks go to Gila Flam for sending me digital copies.

${ }^{48}$ Many thanks to Adèle Stephens, Hirshow's granddaughter, for copies of Yehuda Leib Gordin's letter and the Łomża concert programmes. At the time of writing, all Hirshow's own works performed in this concert must be assumed sadly lost.

${ }^{49}$ According to his granddaughter Adèle, Hirshow had himself been a regular attendee of clandestine prerevolutionary political meetings in Vitebsk.

${ }^{50}$ Hirshow's own words come from a speech he made in December 1950 at Glasgow's Grand Hotel to celebrate 25 years as Reader/Chazan of Garnethill synagogue (text courtesy of Adèle Stephens).

${ }^{51}$ Ibid.

52 Ibid.

${ }^{53}$ Garnethill Minutes for 1925 note that Hirshow had agreed to a prospective salary of $£ 500$ per annum. Nearly ten years later, Meyer Fomin, Reader of the Gorbals’ most prestigious synagogue, was still only earning £318 per annum. All minute books courtesy of Scottish Jewish Archives Centre.

${ }^{54}$ A.Z. Idelsohn famously made a claim for Jewish music as "the tonal expression of Jewish life and development over a period of more than two thousand years" (Jewish Music, 24). Whilst a little more contingency is helpful, the power of sound to make real and felt connections is a fundamental part of synagogue aesthetics. See e.g. Summit Singing.

${ }^{55}$ Collins, The Jewish Experience, 76-7.

${ }^{56}$ Shipowners William Guthrie Gardiner (c.1848-1935) and his brother James (1855-1937) were amongst the University of Glasgow's most generous benefactors, also endowing Chairs in Physiological Chemistry (1919), Bacteriology (1919), Organic Chemistry (1919) and the Pathology of Diseases of Infancy and Childhood (1928).

${ }^{57} \mathrm{He}$ attended Glasgow University at the same time as his son, although—in a nice nod to Jewish clichés—his son was studying medicine rather than music.

${ }^{58}$ From the university schedules it appears that Hirshow had passed all his exams by 1935, but for unknown reasons he did not submit his cantata until 1938.

${ }^{59}$ According to testimony from his Garnethill colleague Dr IK Cosgrove many years later, Hirshow was, upon his retirement, shortly to be approached to lecture at Jews College, the center of cantorial training in the UK. Sadly, he died before this took place.

${ }^{60}$ Psalm 118 makes up part of Hallel, a joyous festival prayer of thanksgiving.

${ }^{61}$ What seems to be the only surviving original copy of the Cantata was given to Hirshow's former pupil Adrian Isaacs (now resident in Modi'in, Israel) by Hirshow's son Wolff upon his father's death. More recently Isaac's granddaughter Adèle Stephens has made several scanned copies—-for her family, for the National Library of Israel, and for the Scottish Jewish Archives Centre. There also exist in Glasgow two copies of the Cantata in two-piano reduction (with full vocal score) by Frederick Frayling-Kelly, commissioned in 1960, My deep gratitude goes to Garnethill cantor Eddie Binnie, who generously lent me his copy of this reduction, and also to the Scottish Jewish Archives Centre for allowing me free access to their copy of the full score.

${ }^{62}$ Bohlman, "Introduction," 7.

${ }^{63}$ See Loeffler, The Most, 117: "The blunt force of European musical antisemitism and the discomfiting phenomenon of Russian musical philosemitism only reinforced the ethnic logic of Jewish nationalism, which demanded that Jewish musicians devote themselves to producing their own national art."

${ }^{64}$ Miller, "Bloch", 41. Although there is no evidence of any conscious connection to Bloch in Hirshow's work, the shifting relationships between Jewishness, music and 'Jewish' musical materials that certain of Bloch's 
works probe (Ibid., 39-40) are highly pertinent here. See also Alexander Knapp on Bloch’s transition from a 'Jewish composer' to a 'composer of Jewish music' (Knapp, “Ernest Bloch’s”, 19).

65 James Loeffler argues: "For the young Jewish composers and new Jewish audiences in early twentiethcentury St. Petersburgh, music provided a route back to a past they had not necessarily ever known themselves.” (Loeffler, The Most, 127).

${ }^{66}$ Syllabus details from Glasgow University Calendar for the Year 1932-3, held in University of Glasgow Archives (SEN10/74, 155-158 \& 506-512).

${ }^{67}$ Lewin, "Introduction".

${ }^{68}$ Kalib, Musical Traditions, 105.

69 See Jordan, Fromental Halévy but also David Conway’s more critical assessment that “La Juive in fact tells us nothing about Jews in nineteenth-century France or any other era...Ironically, it seems very doubtful that the only great opera written by a Jew about a Jew has anything much to say about Jews at all.” (Conway, Jewry, 218).

${ }^{70}$ As part of their $4^{\text {th }}$ Annual Concert in 1964, Glasgow Jewish Choral Society performed the first movement in piano reduction. The soloists were Harold Barnett (tenor) and Ivor M Plotnikoff (bass), and the pianists were Hilary Rosen and Monty Rosenthal.

${ }^{71}$ In his democratic treatment of vocal registers, Hirshow was also echoing the mixed choir that had been a feature of his own Garnethill synagogue from the start.

${ }^{72}$ Mark Kligman discusses a complementary process in the American Reform Synagogue, in particular Abraham Binder's critique of glorifying God in the synagogue through "the repertoire of the concert hall” (“American Synagogue Music”, 270).

${ }^{73}$ Compiled by David M Davis and Francis L Cohen of London’s New West End Synagogue’s and first published in 1899, the Voice of Prayer and Praise (popularly known as "the Blue Book") remains a staple of British synagogue music.

${ }^{74}$ For example: a 2003 tribute concert given by the Glasgow Hebrew Singers was reported by the Jewish Telegraph under the headline "Garnethill Recalls Hirshow Glory Days" (September 19" 2003), and Scottish Jewish writer Chaim Bermant, unusually gushing, described Hirshow and Cosgrove as “a fine establishment's two finest pillars" (JC, January $\left.9^{\text {th }} 1998\right)$.

${ }^{75}$ Eddie Binnie, personal interview, January $11^{\text {th }} 2018$, Glasgow. 